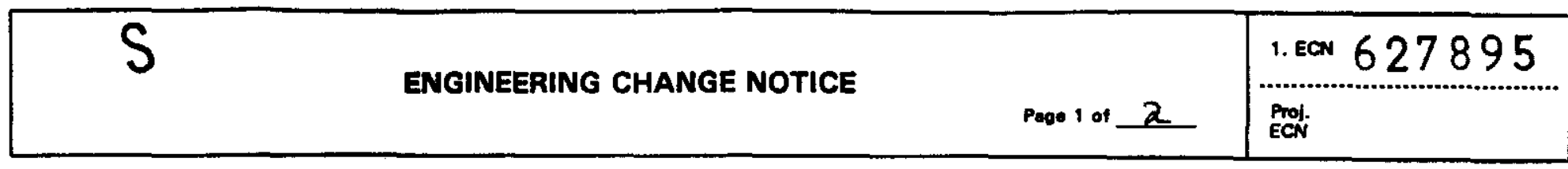

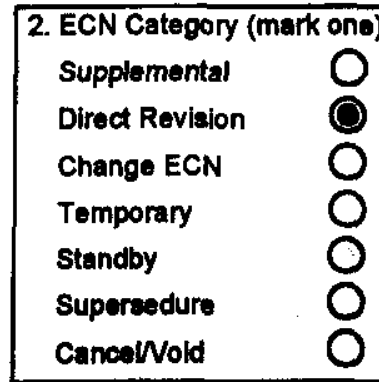

12a. Modification Work

O Yes (nill out Blk. 12b)

ONo (NA Blks. 12b,

3. Orlginator's Name, Organization, MSIN, and Telephone No.

David Tedeschi E6-15, 372-1485

4. USQ Required? 5. Date

6. Project Titte/No.Mork Order No.

Fuel Retieval system/SNE 9. Document Numbers Changed by this ECN (includes
sheat no. and rev.)

HNE-3526 rev 1

12b. Work Package No. 12c. Modification Work Completed

OYes 9 No March 13, 2000

N/A

$\frac{\mathrm{N} / \mathrm{A}}{\text { Design Authority/Cog. Engineer Signature \& }}$

12d. Restored to Original Condition (Temp. or Standby ECNs only)

$\mathrm{N} / \mathrm{A}$

13. Description of Change

13b. Design Baseline Document? $\bigcirc$ Yes $O$ No

This ECN revises "Design Package for Fuel Retrieval system Fuel Handling Tool Modification" HNF-3526 from rev 1 to rev 2 :

The following changes were made:

1) New and modified requirements added

2) Discussion section changed to describe modifications made to stinger and future

modifications

3) Testing section was modified to discuss testing of stinger design(s)

Added in Appendix $\mathrm{C}$ which has in it:

Prototype Evaluation sheet, Prototype Testing Procedure, Requirements Matrix, Design

Verification, Test Spec.

Added Appendix $\mathbf{E}$ which has in it Value Analysis Information:

Criteria, Alternatives/Solutions sheet, Criteria Matrix, and Evaluation Matrix

14a. Justification (mark one)

$\begin{array}{ll}\text { Crlteria Change } & \mathrm{O} \text { These additions will ke } \\ \text { Design Improvement } \mathrm{O} \text { one package. }\end{array}$

Environmental.

Facility Deactivation

As-Found

Facilitate Const.

Const. Error/Omicion

Design Error/Omiasion

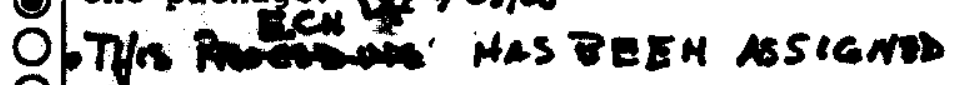

AN Aprewal Des remmice

O) OF N/A Prr HNF-Pro-233, T7.1

$\mathrm{O}$

0

- 1 USQ Screasing Sitawed ho USQ Required, USQ trakking Number K-00-0400,K-Like- $00-0045$

15. Distribution (include name, MSIN, and no. of copies)

* DJ Tedeschi E6-15 1 Advanced*

PA Young $\times 3-881$

GE Stegen $\times 3-76 \quad 1$

TA Delucchi L6-38 1

DR Jackson K5-22 1

Central Files B1-07 1

JM Henderson G6-87 1

JA Dent $\times 3-65 \quad 1$

JC Tucker K5-22 1

SD Godfrey $\times 3-88 \quad 1$

RL Reading Rm. H2-53, 1

FRS Working File* x3-88 1

KBasin Project Files X3-85 1

*IpF $38 \times 3-641$

RELEASE STAMP

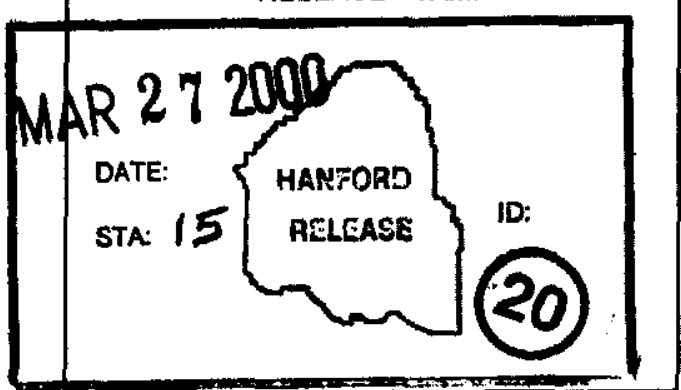




\section{ENGINEERING CHANGE NOTICE}

Page 2 of 2

1. ECN (use no. from po. 1)

627895

16. Dealon Verification

Required

ENGINEERING

CONSTRUCTION

O Yos

Additional $O \leqslant N / A$

Additional $O \leqslant N / \mathrm{A}$

O No

Savinge $O \leqslant \underline{N / A}$

Savings

$\$ N / A$

18. Schedule impact (days)

19. Change Impact Revlew: Indlcate the related documents (other than the engineering documents identified on Side 1) that will be afiected by the change described in Block 13. Enter the affected document number in Block 20.

SDD/DD

Functional Design Crtteria

Operating Speciflcation

Criticallity Specification

Conceptual Design Report

Equipment Spec.

Const. Spec.

Procurement Spec.

Vendor information

OM Manual

FSAR/SAR

Safoty Equlpment Liat

Radlation Work Permit

Environmental Impact Statement

Environmental Report

Environmental Permit

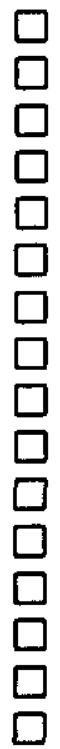

Seismic/Stress Analysis

Stress/Design Report

Interface Control Drawing

Callbration Procedure

Installation Procedure

Maintenance Procedure

Engineering Procedure

Operating Instruction

Operating Procedure

Operational Safety Requirement

IEFD Drawing

Cell Arrangement Drawing

Essential Material Specification

Fac. Proc. Samp. Schedule

Inspection Plan

Inventory Adjustment Request

20. Other Afrected Documents: (NOTE: Documents listed below will not be revised by this ECN.) Signatures below indicate that the signing organization has been notined of other affected documents listed below.

Document Number/Revision

Document Number/Revision

None

\section{Approvals}
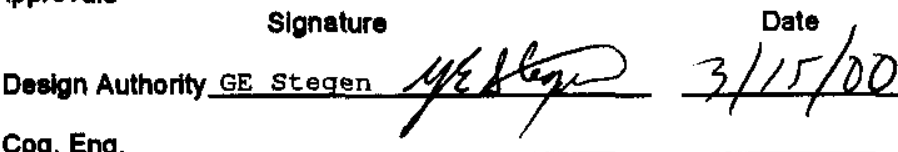

Cog. Eng.

Cog. Mor.

QA

Safety

Environ.

Other

Test Director: DR K5-22

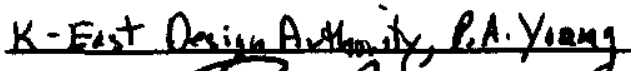

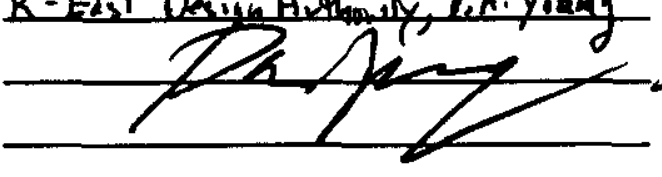

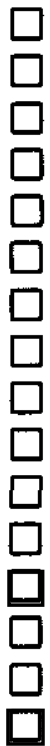

Health Physics Procedure

Spares Multiple Unk Lieting

Tost Procedures/Specification

Component Index

ASME Coded Item

Human Factor Consideration

Computer Soltware

Electric Circult Schodule

ICRS Procedure

Process Control ManualiPian

Process Flow Chart

Purchase Requiation

Tickler File

None
Tank Calibration Manual

Document Number/Revision

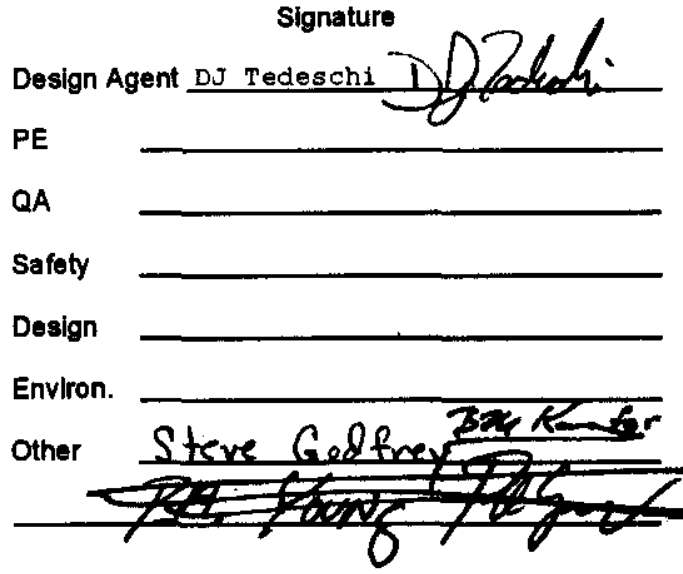

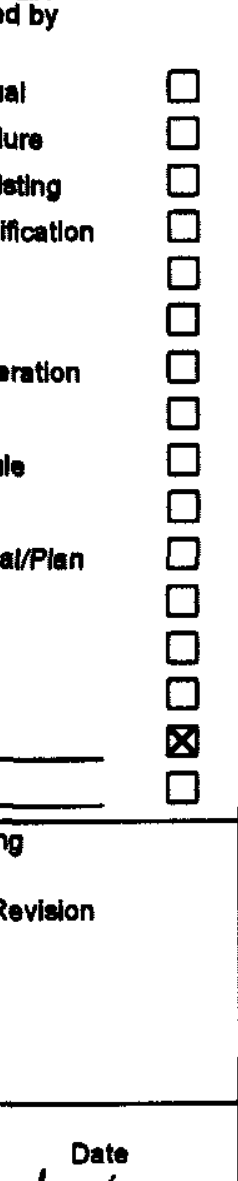

$\mathrm{N} / \mathrm{A}$ 
$S$

HNF-3526

Revision 2

\section{Design Package for Fuel Retrieval System Fuel Handling Tool Modification}

Prepared for the U.S. Department of Energy

Assistant Secretary for Environmental Management

Project Haniord Management Contractor for the

U.S. Department of Energy under Contract DE-AC06-96RL13200

Fuor Hanford

P.O. Box 1000

Richland, Washington 
HNF-3526

Revision 2

ECN-627895

\title{
Design Package for Fuel Retrieval System Fuel Handling Tool Modification
}

\author{
D. J. Tedeschi
}

Fluor Federal Services

Org. Code: $2 F 800$

B\&R Code: EW704000

UC: 2050

Charge Code: CACN 105363 COA CA30 HMFS0011

Date Published

March 2000

Prepared for the U.S. Department of Energy

Assistant Secretary for Environmental Management

Project Henford Management Contractor for the

U.S. Department of Energy under Contract DE-AC06-96RL13200

Fluor Hanford

P.O. Box 1000

Richland, Washington

Fielease Approval $\frac{3-27-00}{\text { Date }}$

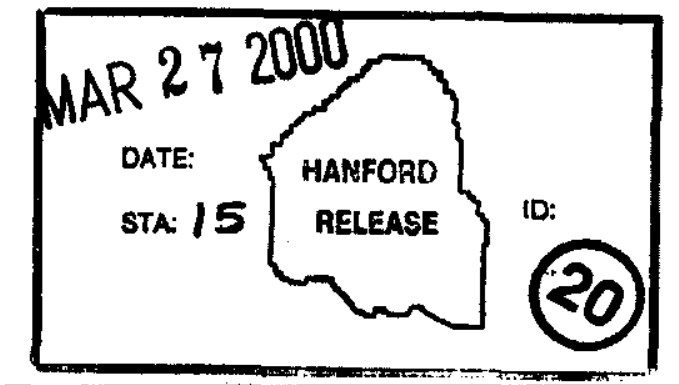

Release Stamp 
HNF-3526, Rev. 2

Key Worda: Spent Nuclear Fuel, Stinger, Fuel Handling Tool, Fuel Retrieval System, Elastomer

\begin{abstract}
Abotract: This is a design package that contains the details for a modification to a tool used for moving fuel elements during loading of MCO Fuel Baskets for the Fuel Retrieval System. The tool is called the fuel handling tool (or stinger). This document contains requirements, development design information, tests, and test reports.
\end{abstract}


TRADEMARK DISCLAMER

Reference heroin to any specific commercial product, process,

or eervice by trade name, trademark, manufacturer, or

otherwise, does not necesearlly conettute or imply its

endoreernent, recommendation, or favoring by the United

states Government or any agency thereof or its contractors or eubcontractors.

This report has been reproduced from the best available copy.

Printed in the Unilud States of Amorica

Total Pages: $\quad 31$ 


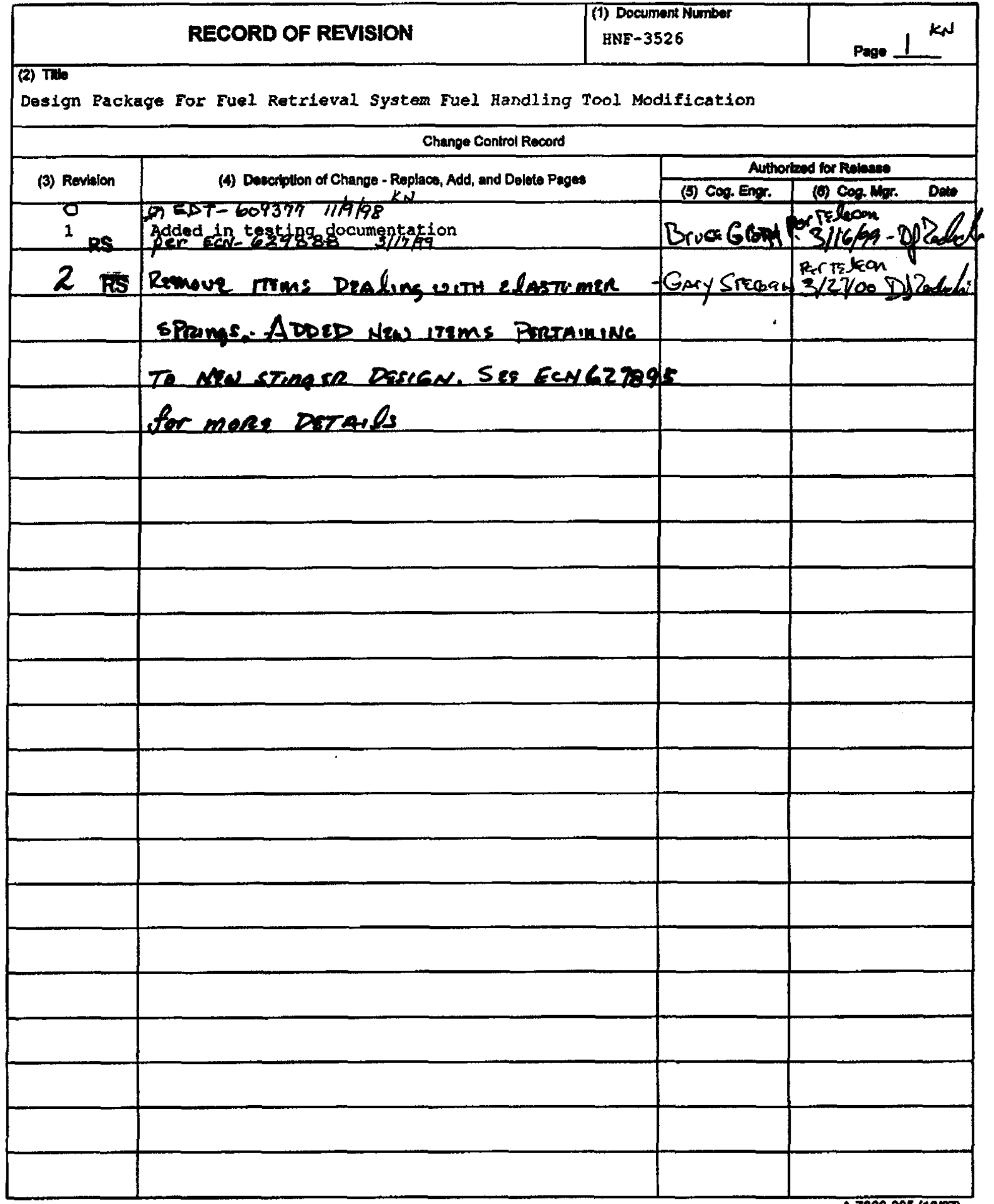




\section{Design Package \\ for}

\section{Fuel Retrieval System Fuel Handling Tool Modification}

HNF-3526 Rev 2

March 10, 2000

By David Tedeschi

of

Fluor Federal Services

1200 Jadwin

Richland, WA 99352

For Spent Nuclear Fuel Project, Fuel Retrieval System Sub-Project in

Fluor Hanford Inc.

P.O. Box 1000

Richland, WA 99352 


\section{Design Package for Fuel Retrieval System \\ Fuel Handling Tool Modification}

March 10, 2000

HNF-3526 Rev. 2

Page 2

\subsection{Introduction}

The Fuel Retrieval System (FRS) Subproject at Hanford's $100 \mathrm{~K}$ basins Spent Nuclear Fuel Project has employed robotic arms (named Konan) to load fuel elements into long term storage baskets.

One Konan uses a fuel handling tool ("stinger tool") to load outer fuel elements into the fuel baskets. The stinger is inserted inside an outer fuel element after the element is placed vertically in a go-no-go gage, used to determine if the fuel can be loaded into an MCO basket socket. The Schilling supplied stinger operates by expanding an elastomer spring inside the outer fuel element. The spring is actuated in its expanded mode when the Konan jaws are opened. The spring's expansion exerts enough force against the inner diameter of the element's wall that it can be lifted.

Use of the Schilling stinger tool in FRS testing and training proved to be inadequate for the expected throughput requirements. This design package provides a new stinger design that will meet requirements listed in this document. The new design will incorporate Schilling's design for attaching the stinger to the Konan.

\subsection{Scope}

\section{$2.1 \quad$ Objectives}

This design package documents design, fabrication, and testing of new stinger tool design. Future revisions will document further development of the stinger tool and incorporate various developmental stages, and final test results.

\subsection{Products Delivered}

Results from this package will deliver the following:

Documents

a) Functions and requirements, analysis, graphical depictions, test specifications, test procedures, and final test reports

b) Hanford formatted drawings and $\mathrm{ECN} /$ modifications to vendor information files 


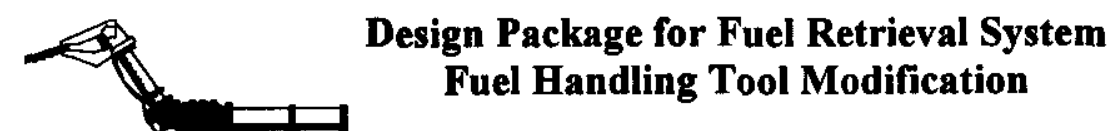

March 10, 2000

HNF-3526 Rev. 2

Page 3

c) Acceptance test requirements for production units

d) Vendor information

\section{Hardware}

a) Prototype stinger tool

b) Final stinger tool

\subsection{Brief Description of Problem}

The actuation mechanism of the stinger provided by Schilling, is prematurely failing due to loads it endures under normal basket loading conditions. High concentrated stresses exceed the yield strength of the actuation mechanism, which causes deformation and eventual failure. The actuation mechanism is a push-pull cable type device. It consists of a wire rope sliding through a wire-braided sleeve. When the Konan jaws are opened, a lever arm attached to the sleeve pushes the sleeve over the wire rope. The sleeve applies a compressive force to the urethane spring that causes the spring to expand. The elastomer spring expansion applies a force against the inner wall of the fuel element, which enables the fuel element to be lifted. A fuel element will be lifted, as long as the frictional forces between the wall of the element and the elastomer spring are not overcome by the weight of the fuel element. See vendor information file CVI 50062, drawing number 1013737, by GEC Alsthrom, for graphical depiction of the Schilling stinger.

\subsection{Products Requirements and Constraints}

General design requirements/criteria for the Spent Nuclear Fuel Project Fuel Retrieval subproject are in HNF-S-0461, Specification For Design Of The SNF Project Fuel Retrieval Subproject. The following additional requirements apply specifically to the stinger tool.

\subsection{Dimensional/Physical Constraints}

a) Stinger will pick up an outer fuel element that is placed in the vertical position but not be required to pick up an inner fuel element.

b) Length of the actuator mechanism is approximately $18+2,-0$. inches but will be determined by testing through successful loading of an dummy outer fuel element into an MCO basket.

c) Stinger end-effector must be able to accommodate the following dimensions:

Fuel Elements

- Outer fuel element maximum inside diameter: 1.779 inches. 


\section{Design Package for Fuel Retrieval System Fuel Handling Tool Modification}

March 10, 2000

- Outer fuel element minimum inside diameter: 1.691 inches. (Dimensions taken from drawing number $\mathrm{H}-1-39775$ )

- Assume outer fuel element weighs approximately $35 \mathrm{lbs}$. in air. Reference HNF-SD-SNF-TI-009, rev. 2, 105-K Basin Material Design Basis Feed Description for Spent Nuclear Fuel Project Facilities.

Based on the above information, the design parameters are the following:

a) Stinger can pick up fuel elements weighing $35 \mathrm{lbs}$. (dry weight) with inside diameters ranging from 1.64 to 1.9 inches.

b) Stinger can pick up a fuel elements weighing $35 \mathrm{lbs}$. (dry weight) when its end-effector is inserted in the element a minimum of .25 inches.

\subsection{Environmental Constraints}

a) Stinger material must be able to withstand the effects of a high radiation field of $40 \mathrm{rem} / \mathrm{hr}$ for 90 days. This value is a conservative interpretation of BNFL Inc. Report L/B-SD-SNF-RPT-04, Radiological Shielding Design Plan for the SNF Fuel Retrieval Project.

b) Stinger shall be submersible in deionized water at a temperature of 50 ${ }^{\circ} \mathrm{F}$ for its design life.

\subsection{Operational Requirements}

a) Stinger should operate for a minimum period of 3 months assuming 3 shifts per day, 7 days a week, and process about 140 fuel assemblies per day. The stinger life expectancy should be 90 days, based on these assumptions.

b) Stinger shall be able to operate under 7-20 feet of water.

c) Stinger actuation design shall take into account the following possible forces induced on it in the various directions:

- A tensile force due to lifting the fuel element (approximately) 35 lbf dry weight.

- A compressive force due to placement of element. Actual amount of force is unknown and may vary with the stinger design. However, an estimated maximum force is about 400 lbf. 


\section{Design Package for Fuel Retrieval System Fuel Handling Tool Modification}

March 10, 2000

- A lateral force due to inserting the stinger in the element, rotating the fuel basket, and placing an element inside the basket. Actual amount of force is unknown.

d) Stinger shall be able to be inserted in a fuel element and used to rotate the fuel basket.

e) Stinger tool shall be flexible enough to hang plumb when being inserted into an element and when trying to insert an element into a fuel basket. The design needs to accommodate a free motion of the block \pm 6 inches in a hemispherical direction.

f) Stinger shall not cause damage to the camera or hinder wrist movement when wrist rotates. Upon wrist rotation, it is desired that the stinger hangs with a tip to toe distance of 1 foot.

g) Stinger will not be used to pull fuel from a canister.

h) Stinger should account for potential snags that could produce a load of $350 \mathrm{lbf}$ in tension. (This reemphasizes requirement $4.3 \mathrm{C}$ ).

\subsection{Maintenance Requirements}

a) Stingers will be thrown away unless there is an inexpensive method for replacing failed parts.

b) The Schilling supplied stinger block that attaches the stinger to the Konan arm shall be used as a part of any new design. The block has been designed for easy attachment and removal from the Konan and it has been accepted by Operations.

c) Stinger shall be fully retrievable if it fails when inside a fuel element. Note: This requirement was not incorporated in the value analysis evaluation of the design but was accounted for in the designs.

\subsection{Applicable Laws, Regulations, and Standards}

Applicable Fluor Daniel Hanford Engineering and SNF Project procedures shall be used for documenting development stages of design, reviews, and approvals of engineering documents. 


\section{Design Package for Fuel Retrieval System \\ Fuel Handling Tool Modification}

March 10, 2000

HNF-3526 Rev. 2

Page 6

\subsection{Additional Objectives}

These objectives are to be considered when evaluating prototypes that meet all the requirements but need additional reasons for determining the best design.

- Fabrication cost

- Higher life expectancy

- Takes abuse well

- Handles better/minimal aligning required for deployment

- Minimal training required

- Operator preference

\subsection{Development of Product}

\subsection{Management of Task}

\subsubsection{Engineering}

Engineering will be done using a team made up of staff from Fluor Federal Services, Cogema, and Pacific Northwest National Laboratories. Documents will be approved by Fluor Hanford Inc. Fuel Retrieval System Design Authority(s).

\subsubsection{Procurement}

Developmental materials will be procured using credit cards from Numatec, Cogema, or Pacific Northwest Laboratories. Final parts will be ordered using appropriate Quality levels as directed by the Design Authority(s).

\subsubsection{Initial Project Fabrication and Construction}

Fluor Federal Services will be responsible for managing final fabrication and DynCorp or HAMTC personnel will be responsible for final construction. The FRS Project Manager will determine use of another contractor for managing the fabrication as required.

\subsubsection{Prototype}

Prototypes will be assembled using Fluor Federal Services, Cogema, and Pacific Northwest Laboratories. The Engineer in charge will maintain redline control of prototype fabrication drawings/sketches. Prototype testing and test results will be documented by the FRS test engineer. 


\section{Design Package for Fuel Retrieval System Fuel Handling Tool Modification}

March 10, 2000

\subsection{Discussion of Development}

Operational testing of the Schilling stinger tool revealed that the tool had to be modified significantly for long-term use. See previous revisions of this document for a history on what was done to reach this determination.

The first modification made was a replacement of the large elastomer spring. Operational testing showed that the stinger tool needed to lift an outer element only and that the inner elements would be loaded with the jaws. This led to modifications accommodating outer elements exclusively. Based on engineering experiences with similar devices, it was decided to use an expanding collet rather than the elastomer spring. After prototype testing several collets with various materials, Inconel 718 gave the best results. It has a yield strength of $170 \mathrm{ksi}$ if heat treated, which proved to provide the collet with necessary spring properties.

The collet is a split tube with concentric internal angles on either side. The collet expands when two stainless steel conical end pieces, cut to the same angle as the collet, are forced into the collet. The dual pieces cause the collet to uniformly expand which helps prevent it from deforming if it is inserted only partialy into an element.

Operational testing also demonstrated us of the Schilling mounting block that connects the stinger to the Konan and its ease of removal. A separate tool was developed to remove the block and can be found on drawing H-183905, "K-Basin FRS Konan Manipulator Fuel Tool Extractor Device".

Observation of the failed Schilling tool and other prototypes showed that failure occurred primarily in the actuation mechanism that expands the collet. A team consisting of Operations, Engineering and Technicians were assembled to evaluate the problem. The team refined the stinger requirements (refinements have been incorporated in section 4.0) and brainstormed 7 solutions. Solutions can be found in Appendix F. The team decided that the final design should use the collet design with the Schilling mounting block and concentrate efforts on modifying the actuation method. Several solutions were brainstormed and then evaluated using a value analysis process.

A value analysis process ranks the criteria/requirements of the tool and evaluates them against each potential design (with what knowledge is known about the design). The designs are then ranked based on the highest score it receives. Analysis documentation including the Criteria Matrix, Evaluation Matrix, and the Criteria can be found in Appendix F. 


\section{Design Package for Fuel Retrieval System \\ Fuel Handling Tool Modification}

March 10, 2000

HNF-3526 Rev. 2

Page 8

The value analysis showed the design most able to meet the requirements was the reverse acting design that has the collet normally expanded. The actuation mechanism is used to relieve the expansion when the jaws are opened. The second ranked design uses self contained hydraulics as a means for actuation the collet. This design uses the water from the basin as its hydraulic fluid. The third ranked design is a modification of the existing style with a cable inside a sheath for its actuation.

Fluor Federal Services, Coegma, and Pacific Northwest National Labs each took one of the three designs and will built a prototype for testing. Results from each will be documented in this package upon the next revision.

\subsubsection{Sketches/Drawings}

All graphical depictions will be found in Appendix A. This revision will not contain any.

\subsection{Verification of Product Design}

Verification of the modifications to the stinger will be done through prototype testing. The testing will verify features/requirements listed in section 4 of this document. Upon satisfaction of a prototype, the design(s) will be documented using an $\mathrm{H}-1$ - series drawing and a final tool will be fabricated from a released drawing. Final design verification tests will be performed per the attached verification test specification and attached in Appendix D. Acceptance testing of fabricated stingers to be used in the basin will be done to confirm that the tool was fabricated correctly and that it still operates like the prototype stinger. This testing will be done before being used in the field.

Additionally,

\subsubsection{Analysis}

\subsubsection{Calculations}

There were no calculations done.

\subsubsection{Testing}

The schedule does not permit an allotted time for long term testing of all three designs. All three will be fabricated and individually tested on the Konan. The design with the greatest potential for succeeding will be issued to the field for in-pool use. 


\section{Design Package for Fuel Retrieval System \\ Fuel Handling Tool Modification}

March 10, 2000

HNF-3526 Rev. 2

Page 9

Prototype testing will be documented using an evaluation sheet attached in Appendix C. This sheet is developed by the requirements matrix also found in the Appendix $\mathrm{C}$. The matrix ties the requirements to the evaluation and a common testing procedure.

A standard testing procedure will be used as a basis for filling out the evaluation sheet. Other features unique the individual design will be added as necessary by the design engineer. This procedure is found in Appendix $\mathrm{C}$ as well.

Results from the prototype testing will be incorporated into this design package upon the next revision.

\subsection{Turn Over of Product}

\subsection{Final Design Description}

The final design(s) will be incorporated into the next revision of this design package.

\subsection{References}

Radiological Shielding Design Plan for the SNF Fuel Retrieval Project. BNFL Inc. Report L/B-SD-SNF-RPT-04

105-K Basin Material Design Basis Feed Description for Spent Nuclear Fuel Project Facilities. HNF-SD-SNF-TI-009, rev. 2

Specification For Design Of The SNF Project Fuel Retrieval Subproject. HNF-S-0461

Final Report -Spent Nuclear Fuel Retrieval System Manipulator System Cold Validation Testing. PNNL - 12135 


\section{Design Package for Fuel Retrieval System}

Fuel Handling Tool Modification

March 10, 2000

HNF-3526 Rev. 2

Page A-i

Appendix A

Graphical Depictions of Product 
Design Package for Fuel Retrieval System

Fuel Handling Tool Modification

March 10, 2000

HNF-3526 Rev. 2

Page B-i

Appendix B

Calculations 
Design Package for Fuel Retrieval System Fuel Handling Tool Modification

March 10, 2000

HNF-3526 Rev. 2

Page $\mathrm{C}-\mathrm{i}$

Appendix C

Test Specifications:

Prototype Test Matrix

Prototype Test Procedure

Prototype Test Evaluation Sheet 


\section{Stinger Prototype Evaluation Sheet}

HNF-3526 Rev. 2

Date:

Description of Tool: (title)

Operators (sign and print):

Design Agent (sign and print):

FRS Test director (sign and print):

Brief description of actuation device between collet and lever arm:

1) Initial reading of collet O.D. with jaws closed: inches

2) Initial reading of collet O.D. with jaws opened inches

3) When wrist on Konan arm rotates it:(circle the letter if it passed, else explain under comments)
a) does not touch camera
b) does not hinder movement in anyway

c) has a tip-toe measurement of inches

\section{Comment:}

4) Measurement of actuation mechanism (from block to collet) inches

5) Can the tool pick up the test element with an I.D. of 1.64" several times? Yes / No Comments:

6) Can the tool pick up the full weight test element with an ID of 1.9 " several times? Yes / No Comments:

7) Can the tool pick up the full weight test element with an ID of 1.9 " with collet only 0.25 " engage?

Yes / No Comments:

8) Can the tool pick up the full weight test element with an ID of 1.9" and that's been submerged under water several times?

Yes / No Comments: 


\section{Stinger Prototype Evaluation Sheet \\ HNF-3526 Rev. 2}

Date:

Description of Tool: (title)

Operators (sign and print):

Design Agent (sign and print):

FRS Test director (sign and print):

9) Can basket be rotated using the stinger?

Yes / No Comments:

10) Can a basket be fully loaded and no adjustments need to be made to stinger?

Yes / No Comments:

11) Does the collet hang plumb when trying inserting it into an element?

Yes / No Comments:

12) Do all the elements when lifted hang plumb enough to be inserted into a basket?

Yes / No Comments:

13) Can a failed stinger tool be retrieved if failure is in an element?

Yes / No Comments:

14) Was adjustment necessary to accomplish any of the lifts?

Yes / No Comments:

15) Final readings of collet O.D. with jaws closed:

inches

16) Final reading of collet I.D. with jaws opened: inches

12) Additional observations based on objectives (operability, life expectancy, cost of fabrication...): 


\section{Prototype Testing Procedure \\ HNF-3526 Rev. 2}

Description of Tool: (title)

Document the results of the following procedure steps on the evaluation sheet.

Note: If adjustments are needed to make a lift, then document it on the evaluation sheet and continue on with the test procedure. With each adjustment, measure and record the collet O.D. with the jaws both opened and closed.

1) Place stinger on Konan and set up dummy fuel elements in the go-no-go guage. This should include one with an $\mathrm{DD}$ of at least 1.64". It would be best if test element was not full length in order to check how the elements hang with a light load.

2) Measure the O.D. of the collet with jaws closed.

3) Open the jaws and measure the O.D. of the collet.

4) Cycle the opening of the jaw several times.

5) Measure the O.D. of the collet.

6) Slowly rotate wrist $360^{\circ}$. If it appears at anytime that the rotation could damage or cause the stinger to come in contact with the camera, then stop rotation.

7) Measure the worst case tip-toe distance achieved when rotating wrist.

8) Measure length of actuation mechanism (from block to the collet).

9) Insert stinger into the test pipe with an ID of 1.64 ".

10) Lift element and include some shaking.

11) Repeat steps 6 and 7 several times then remove element from stinger.

12) Insert stinger into the full weight test element with a smooth wall and an ID of 1.9".

13) Lift element and include some shaking.

14) Repeat steps 9 and 8 several times then remove element from stinger.

15) Insert stinger into the full weight test element with a smooth wall and an ID of 1.9" except insert it so that approximately 0.25 " of the collet is all that will catch.

16) Lift element and shake to see if it will hold. Remove element when finished.

17) Fully submerge full weight test element in a bucket of water.

18) Lift element and include some shaking. 


\section{Prototype Testing Procedure}

HNF-3526 Rev. 2

Description of Tool: (title)

Document the results of the following procedure steps on the evaluation sheet.

19) Repeat steps 14 and 15 several times then remove element from stinger.

20) Insert stinger into any dummy fuel element and place it in the fuel basket.

21) Load basket a quarter full.

22) Insert the stinger into one element and rotate basket.

23) Repeat steps 17-19 until the rest of the basket is full.

24) Measure the O.D. of the collet with jaws closed.

25) Open the jaws and measure the O.D. of the collet.

Apply the following steps on stinger designs that have the potential for getting stuck in a fuel element if failure of actuation mechanism should occur.

26) Insert stinger into any dummy fuel element.

27) Assume stinger has failed. Initiate retrieval process designed for that tool.

\section{ADD ADDITIONAL STEPS UNIOUE TO THE DESIGN BELOW}




\section{Operational Requirements Cross Matrix for Stinger Evaluation}

HNF-3526 Rev 2

Date:

Description of Tool: (title)

Page C-5

Design Agent (sign and print):

\section{Requirements Matrix}

\begin{tabular}{|c|c|c|}
\hline Requirement & Procedure step & Evaluation step \\
\hline $\begin{array}{l}\text { Stinger can be inserted into a pipe standing } \\
\text { vertically upright with an I.D. of 1.64" }\end{array}$ & 9 & 5 \\
\hline Stinger can lift pipe with an I.D. of $1.69^{\prime \prime}$ & 10 & 5 \\
\hline $\begin{array}{l}\text { Stinger can lift pipe with an I.D. of } 1.9 \text { " with } \\
\text { a weight of } 35 \mathrm{lbs} \text {. (dry weight). }\end{array}$ & $12-13$ & 6 \\
\hline $\begin{array}{l}\text { Stinger can lift pipe with an I.D. of } 1.9 \text { " with } \\
\text { a weight of } 35 \text { lbs. (dry weight) when collet } \\
\text { is only inserted in } .25 \text { " }\end{array}$ & $14-15$ & 7 \\
\hline $\begin{array}{l}\text { Weighted test pipe can be shook around with } \\
\text { out coming off the stinger }\end{array}$ & $10,13,18$ & $5,6,7$ \\
\hline $\begin{array}{l}\text { Weighted test pipe can be lifted and shook } \\
\text { around with out coming off the stinger after } \\
\text { being in water. }\end{array}$ & $17-19$ & 8 \\
\hline $\begin{array}{l}\text { No adjustments have to be made to the } \\
\text { stinger. }\end{array}$ & N/A & 14 \\
\hline $\begin{array}{l}\text { Stinger can successfully load several baskets } \\
\text { and no adjustments have to be made }\end{array}$ & 13 & 10,14 \\
\hline $\begin{array}{l}\text { Fuel basket can rotated using a stinger in fuel } \\
\text { rod. }\end{array}$ & 22 & 9 \\
\hline Length of actuator is $18 " \pm 2.0$ & 8 & 4 \\
\hline $\begin{array}{l}\text { Wrist rotates and stinger does not damage } \\
\text { camera, hinder movement of the wrist, and } \\
\text { has tip to toe distance of about } 1 \text { foot. }\end{array}$ & $6-7$ & 3 \\
\hline Stinger tool will handle potential snags. & $\begin{array}{c}\text { Steps } 20-23 \text { should } \\
\text { verify this requirement }\end{array}$ & 10 \\
\hline $\begin{array}{l}\text { Stinger can be retrieved if failed or will fail } \\
\text { in a condition that it won't be left in fuel } \\
\text { element. }\end{array}$ & $24-25$ & 13 \\
\hline $\begin{array}{l}\text { Stinger can handle the loading as specified in } \\
\text { the document } 4.3 . \mathrm{c}\end{array}$ & $\begin{array}{l}\text { This difficult to test. } \\
\text { Actual loading will } \\
\text { more account for this } \\
\text { loading }\end{array}$ & 10 \\
\hline $\begin{array}{l}\text { Stinger tool needs to be flexible enough to } \\
\text { hang plumb when: 1) being inserted into an } \\
\text { element and 2) when trying to insert an } \\
\text { element into a fuel basket. The design needs } \\
\text { to accommodate a free motion of the block } \pm \\
6 \text { inches. The direction of this is in a } \\
\text { hemisphere. }\end{array}$ & $\begin{array}{l}\text { Actual loading of } \\
\text { baskets will account for } \\
\text { test this. }\end{array}$ & 11,12 \\
\hline
\end{tabular}




\begin{tabular}{|l|l|l|}
\hline \multicolumn{3}{|c|}{ Operational Requirements Cross Matrix for Stinger Evaluation } \\
Date: & \multicolumn{2}{|c|}{ Page C-6 } \\
Design Agent (sign and print): & \multicolumn{2}{|c|}{ Description of Tool: (title) }
\end{tabular}




\section{Appendix D}

Design Verification Test Specification and Acceptance Test Specification 


\title{
Test Specification
}

\section{FRS Manipulator Fuel Stinger Tool}

\author{
Revision No. 0
}

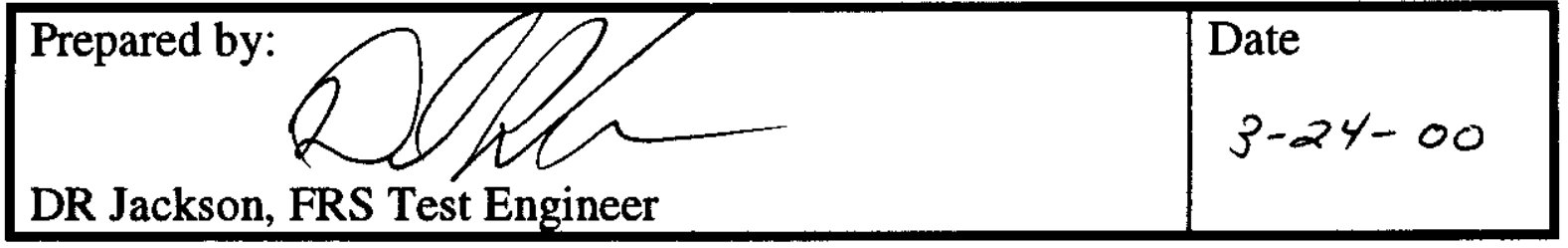




\begin{tabular}{llr}
\hline SPENT NUCLEAR FUEL PROJECT & Document: & HNF- 3526, Rev. 2 \\
TEST SPECIFICATION FOR & Page: & Page D2 of D3 \\
MANIPULATOR FUEL STINGER TOOL & Effective Date: & $03 / 24 / 00$ \\
\hline
\end{tabular}

FACILITY: 305 Bldg./APEL

SYSTEM: FRS Manipulator Fuel Stinger Tool

\subsection{SCOPE}

This test specification is for design verification only.

The following major components are included in this test specification:

$1.1 \quad$ FRS Manipulator

1.2 Manipulator Fuel Stinger Tool(s)

1.3 Manipulator Fuel Stinger Removal Tool

\subsection{REFERENCES}

2.1 Performance Specification for the Procurement of the Manipulators, SNF-FRS-SPC-003, Rev. 3.

2.2 Schilling Robotics Operations \& Maintenance Manual for Konan Manipulator

2.3 Specification for the Procurement of the FRS In-Pool Equipment, SNF-FRS-SPC-007, Rev. 4.

2.4 Test Plan and Strategy for the Fuel Retrieval Sub-Project, HNF-SD-SNF-TP-027, Rev. 2.

\subsection{PLANT CONDITIONS}

3.1 Hydraulic Power Unit is operational.

3.2 EOC PCs are operational

3.3 EOC Camera Viewing System is operational

3.4 Trained Manipulator Operators are Available 


\begin{tabular}{llr}
\hline SPENT NUCLEAR FUEL PROJECT & Document: & HNF- 3526, Rev. 2 \\
TEST SPECIFICATION FOR & Page: & Page D3 of D3 \\
MANIPULATOR FUEL STINGER TOOL & Effective Date: & 03/24/00 \\
\hline
\end{tabular}

\subsection{TEST REQUIREMENTS AND ACCEPTANCE CRITERIA}

\begin{tabular}{|c|c|c|}
\hline Item & Test Requirement & Acceptance Criteria \\
\hline & Key Functions: & \\
\hline 1 & $\begin{array}{l}\text { Tool does not interfere with or hamper sorting } \\
\text { the fuel, scrap, and debris }\end{array}$ & $\begin{array}{l}\text { Tool does not get hung up on table, baskets, or become } \\
\text { entangled with other parts of the manipulator, table, } \\
\text { basket, or other equipment normally maintained in the } \\
\text { work area. }\end{array}$ \\
\hline 2 & $\begin{array}{l}\text { Tool provides functional performance to load } \\
\text { fuel into the MCO fuel basket }\end{array}$ & $\begin{array}{l}\text { Tool can be easily manipulated to perform fuel loading } \\
\text { tasks (acquire fuel elements from go/no-go gage and } \\
\text { load them into the MCO fuel basket sockets) }\end{array}$ \\
\hline 3 & $\begin{array}{l}\text { Tool is easily installed and removed using the } \\
\text { long-pole extractor device designed for } \\
\text { stinger tool removal (Ref. Drawing No. H-1- } \\
83905 \text { ). }\end{array}$ & $\begin{array}{l}\text { Tool hardware does not interfere with, or prevent, tool } \\
\text { installation and/or removal when using the specified } \\
\text { long pole tool. }\end{array}$ \\
\hline \multirow[t]{2}{*}{4} & Tool demonstrates reasonable reliability & $\begin{array}{l}\text { Tool functions properly and shows no signs of } \\
\text { excessive wear after approximately } 100 \text { machine hours } \\
\text { of testing (manipulator hour meter hours based on } 18 \\
\text { workdays X } 6 \text { machine hours per workday) }\end{array}$ \\
\hline & Key requirements: & \\
\hline 1 & $\begin{array}{l}\text { Tool easily acquires dummy elements of all } \\
\text { expected diameters }\end{array}$ & $\begin{array}{l}\text { Tool maintains expansion range of } 1.64 " \text { to } 1.90 " \\
\text { Tool hangs reasonably "plumb" (subjective) } \\
\text { Tool allows operator to easily acquire elements } \\
\text { (subjective) } \\
\text { Tool holds elements securely and does not drop them }\end{array}$ \\
\hline 2 & $\begin{array}{l}\text { Tool repeatedly successful in lifting wet, full- } \\
\text { weight, dummy elements of } 35 \mathrm{lbs} \text {. dry- } \\
\text { weight }\end{array}$ & $\begin{array}{l}\text { Tool is used to lift full weight dummy element in a } \\
\text { wetted condition before, during, and after completion } \\
\text { of reliability test run. ( } 6 \text { distinct lifts per test check). }\end{array}$ \\
\hline 3 & $\begin{array}{l}\text { Tool repeatedly successful in lifting elements } \\
\text { with a nominal } 0.25 \text {-inch insertion depth. }\end{array}$ & $\begin{array}{l}\text { Tool is used to lift full weight dummy element in a } \\
\text { wetted condition before, during, and after completion } \\
\text { of reliability test run with only a nominal } 0.25 \text {-inch } \\
\text { insertion depth. ( } 6 \text { distinct lifts per test check). }\end{array}$ \\
\hline 4 & $\begin{array}{l}\text { Tool to operate with a minimum expansion } \\
\text { range of } 1.64 \text { inches to } 1.90 \text { inches. }\end{array}$ & $\begin{array}{l}\text { Tool expansion to be checked prior to, during, and after } \\
\text { completion of reliability test run. Measured expansion } \\
\text { must include the stated range, but can exceed it. }\end{array}$ \\
\hline 5 & $\begin{array}{l}\text { Tool design accommodates free motion of the } \\
\text { wrist block to a } 6 " \text { hemisphere. }\end{array}$ & $\begin{array}{l}\text { Insert tool into a fuel element and move wrist about in } \\
\text { approximate 6" hemisphere. (subjective) }\end{array}$ \\
\hline 6 & $\begin{array}{l}\text { Tool does not wrap around wrist or become } \\
\text { entangled with other components when wrist } \\
\text { is rotated. }\end{array}$ & $\begin{array}{l}\text { Tool remains un-entangled during normal fuel loading } \\
\text { functions, including jaw actions and stinger use. } \\
\text { (subjective) }\end{array}$ \\
\hline
\end{tabular}


Design Package for Fuel Retrieval System

Fuel Handling Tool Modification

March 10, 2000

HNF-3526 Rev. 2

Page E- $i$

Appendix E

Design Verification Test Report 
Design Package for Fuel Retrieval System Fuel Handling Tool Modification

HNF-3526 Rev. 2

March 10, 2000

Page $F-i$

Appendix F

Value Analysis 


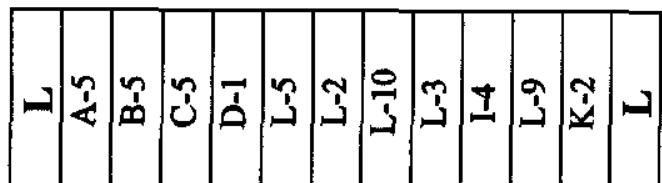

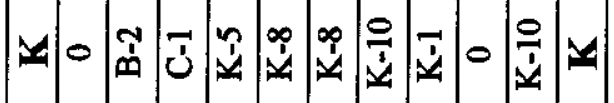

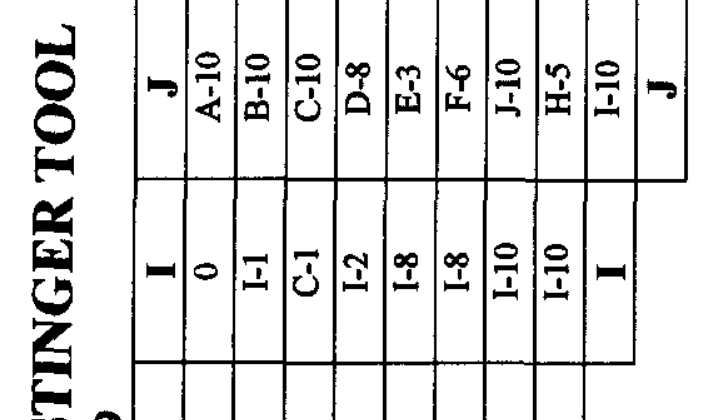

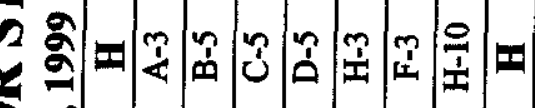

$\theta$ m

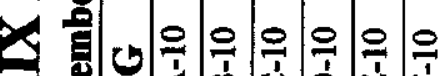

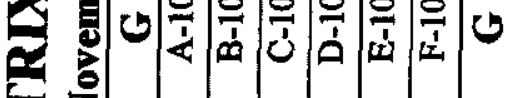

$\approx 2$

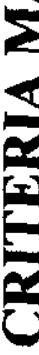

$$
\begin{aligned}
& \text { má }
\end{aligned}
$$

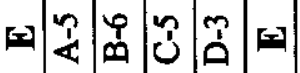

-

$$
0 / 200
$$$$
\infty \underset{\sim}{2}=
$$

告

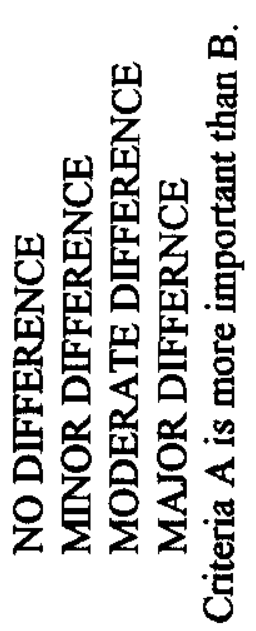

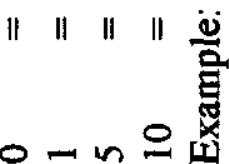

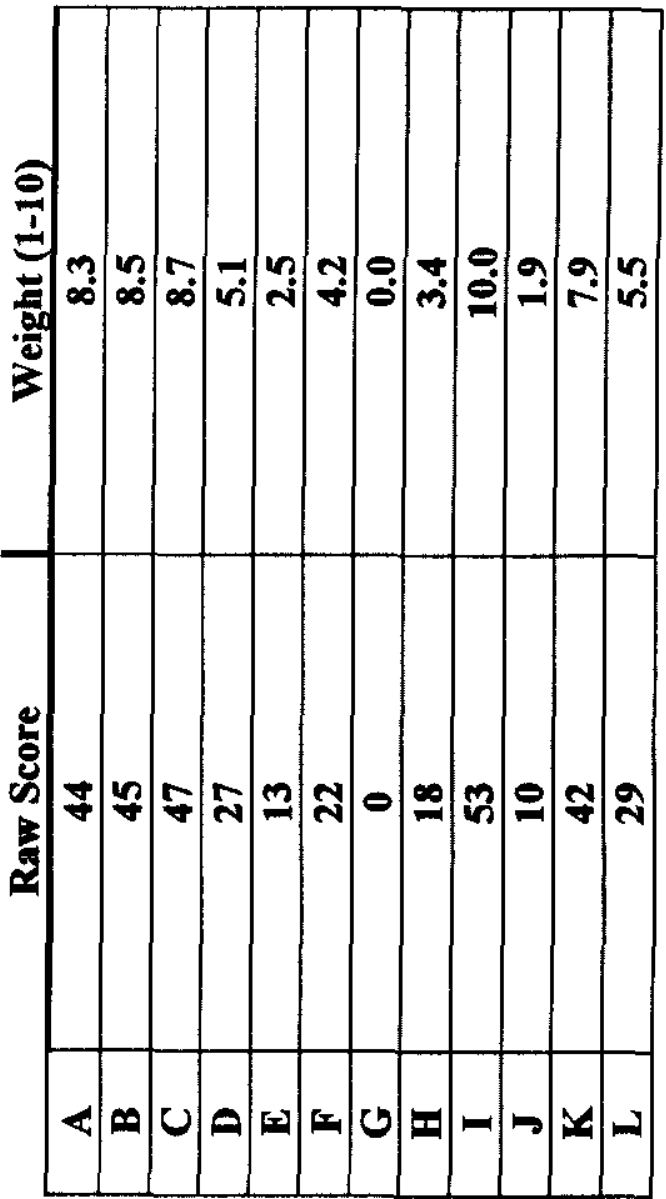




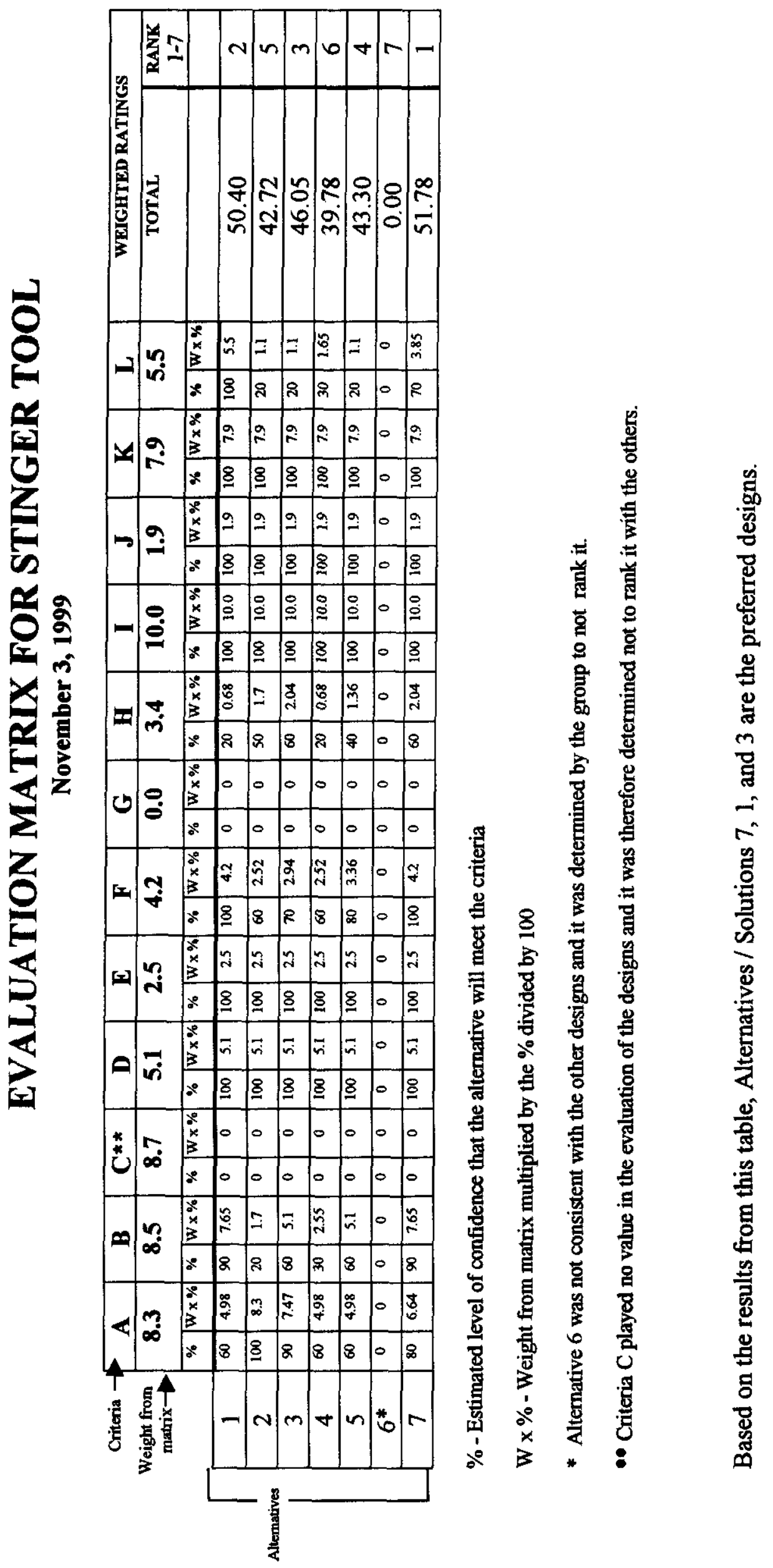

